\title{
Higher Education in the United States and Brazil: How the Two Systems Origins Shaped Their Further Development
}

\author{
Arabela Campos Oliven \\ Education Graduate Program, Federal University of Rio Grande do Sul, Porto Alegre, Brazil \\ Email: arabelaoliven@gmail.com
}

Received 13 August 2014; revised 2 September 2014; accepted 12 September 2014

Copyright (C) 2014 by author and Scientific Research Publishing Inc. This work is licensed under the Creative Commons Attribution International License (CC BY). http://creativecommons.org/licenses/by/4.0/

c) (i) Open Access

\begin{abstract}
This article draws a parallel between higher education in the United States and Brazil placing emphasis on its different origins. The college tradition in the United States began with Harvard in the seventeenth century soon after the pioneers settled in the new land. These institutions were private, closer to their Board of Trustees than to the British Crown, and had a deeply religious character. Since one of their objectives was to train religious leaders, character formation was very valued. Located far from city centers, colleges used to operate as almost a total institution. The first Brazilian higher education institutions were created in the early nineteenth century when the Portuguese Royal family left Lisbon for its colony, Brazil. Schools of Medicine, Law, Pharmacy, etc. were called Faculdades. Highly elitist they were located in large cities. They followed the model of Napoleonic Great French Schools, which were secular institutions aimed at training professionals. United States and Brazil have quite different higher education systems, but both still sustain, to a large extent, their respective marks of origin and pay tribute to them.
\end{abstract}

\section{Keywords}

History of Higher Education, Brazil, USA, Colleges, Faculdades

\section{Introduction}

This article seeks to tease out differences between American and Brazilian higher education, underscoring how the first institutions of these two systems shaped in many ways their further development. It shows how the model upon which the first institutions were founded in both countries became an indelible mark, operating in times of continuity as well as during changes introduced by domestic policies and/or legal educational reforms. 
Commenting on the more recent American influence in Brazilian system of higher education since the 1968 University Reform and the development of the graduate system that followed it, references will be made to the relationship between undergraduate and graduate studies in both countries.

\section{Higher Education in the United States}

\subsection{The Founding Institution: The American College}

The first higher education institution in America's English colonies was Harvard College, founded in 1636 by a Calvinist group, not too long after its arrival in the New World. During the colonial period, another seven colleges of different denominations were established. England was the inspiration for the British colonies in the New World. In the metropolis the higher education system was made up of a high number of colleges affiliated with one of two traditional universities, which were the only institutions entitled to grant academic degrees: Oxford and Cambridge. This model was too complex for the colonies' limited socioeconomic realities.

On the one hand the colonial colleges incorporated multiple aspects of the British university tradition as best as they could, on the other they were also largely independent from the British Crown. Many of those who left England at that time were fleeing religious persecution. The settlers belonged to different Protestant denominations, and the founders of colonial colleges-mostly non-conformists-dreaded England's interference in the religious orientation of higher education institutions.

Colonial colleges trained mostly pastors and religious leaders for the new communities. This required that character formation were put first, through reading and discussing the Bible, studying the classics, and a rigid discipline that included regular assistance to religious services and close contact between students and professors, where the latter were considered models of conduct. These higher education institutions functioned as a boarding school. The professors, who also lived in the colleges, were in charge of training the young students by taking up the parental role and providing an example to be followed. This configuration was called in loco parentis (Rudolph, 1990).

The founders of these colleges were more loyal to local sponsors than to the British Crown. This gave origin to a core element of the colleges' power structure: the Board of Trustees. This was a non-resident group open to laymen who governed the institution, established its guidelines, and chose its president, who was in charge of implementing the policies devised by the founders and the council. The faculty was a minor stakeholder in this power structure; the professors did not hold the knowledge, the organization or the tradition of medieval masters, and relied on those who sponsored them. Due to the colleges' limited dimension, power struggles were not so significant.

In the colonial period, the colleges public or private character was often conflated. Each colony had a fairly homogeneous population, and religious affiliation permeated almost all social relations. Upon U.S. independence, some Republican leaders came to see public - and therefore secular-education as a goal. A watershed in the struggle between public and private control, and between centralization and diversification, was the case of Dartmouth College (Graham, 1990). The British Crown had authorized the college's foundation, but at a moment when the U.S. turned independent, a power struggle in the college followed the death of its first president and the appointment of his son as successor. The Board of Trustees and local politicians from New Hampshire (state where the college is located) thus vied for control of the institution's future.

In 1816, the state government sought to enact a law creating the University of Dartmouth, to be based on the original college. This would require the consent of its Board of Trustees, which was obtained through subterfuge: the number of trustees was increased, thus conforming a council favorable to the creation of the new university. Since the original council refused to obey the new law, the same institution-Dartmouth College and Dartmouth University-remained with two administrative bodies. This led the original council to sue the college's treasurer when he refused to comply. The question was whether Dartmouth was a public institution or not-a stalemate that was taken to the courts.

As would be expected, the State Court decided in favor of public control of the institution. The case was then taken to the Supreme Court, and the justices stood by the original council. The claim was that the license that had been granted by the ancient metropolis was a contract that should be honored. To create a public university run by the state would be to bow to political influence, something that was not advisable and could lead to loss of confidence by its private benefactors.

In a sense, this decision equated educational institutions to corporations. It encouraged the establishment of 
numerous colleges by different religious denominations, at arm's length from government influence. This contributed to increased diversity, and that remains a characteristic of the American system to this day. It also contributed to sectarianism by reinforcing ethnic-religious differences among the general population.

Since its origins, higher education in the U.S. was directed to the training of pastors and other community leaders. It was defined as education for men, and more specifically, for white men. Beginning in the nineteenth century, this monopoly was challenged by a typically American formula: the emergence of colleges for women and blacks (Brubacher \& Rudy, 1976).

Colleges reproduced values of a largely rural society in their architecture, centered around a "green"-a square parcel of lawn encircled by the main buildings (chapel, library, classrooms, dorms, labs, and so forth). Located far from city centers, colleges operated almost like total institutions. Their mission was not just to mold the spirit of young students, but also to gain their hearts-through their religious identities, regional and ethnic diversity, gender and race specificities. This dense spiritual atmosphere imprints a deep, lifelong mark in all those who attended the same college: the so-called alma mater. Thus the importance traditional American universities assign to financial support from alumni (Leslie, 1992).

\subsection{Living in the College: The Greek System and Other Forms of Sociability}

In the second half of the nineteenth century, university students started multiple organizations such as literary groups, secret societies, football teams, social clubs, and fraternities. The latter were closed groups of students, who lived together in houses within or around the campi, and which can even today be identified by Greek letters displayed on their front walls. The first fraternities were exclusive for males. After a while, female students founded their own sororities. The numerous fraternities and sororities scattered around the country make up the Greek system, which organizes them at a national scale, operating as a support and social network. Through this system, students may get introduced and/or recommended for trainee positions, jobs, or loans; they also gain a particular identity.

In order to belong to a fraternity, it is not enough to pay a monthly fee; one has to pledge and be accepted. The applicant fills out a form including a photograph and personal data, and must specify the reasons why he chose that particular fraternity. The senior residents choose the new associates. It is useful for a candidate to have a relative who belongs or has belonged to a fraternity - a legacy that improves the odds of being chosen. Particular rites mark the passage of one's status from pledged to brother (that is, a member of the organization). The pledged must face some challenges in order to show his worth, that he deserves to be part of the organization. Each new member is assigned a senior brother, who will guide them in their adaptation to life in college and in the fraternity. There is a ritual for welcoming the freshmen, who go on to become brothers for life. To belong to a fraternity demands loyalty, since one's connection with the organization persists and must be variously expressed: from supporting social works and helping build new university accommodation for new members, to financial contributions to the college.

Many are the reasons why fraternities and sororities have multiplied and remain active. In the beginning, some of them aimed at deepening knowledge about the classic literature, since previously to the Civil War (1861-1865) many colleges offered limited intellectual experience to the students due to the sectarianism that prevailed in most higher education institutions.

Fraternities' more homely atmosphere was also supportive of freshmen adaptation to their new life on campus. To leave one's family for doing undergraduate studies elsewhere often means never returning to live in the parental home. Fraternities therefore play the role of a new family, a family of senior and junior-that is, more and less experienced-brothers.

From a sociological perspective, it can be said that as colleges became more democratic, opening their doors to lower cultural capital groups, the fraternities increasingly took on a social screening function. They make public the fact that some are better born, while others have to rely on the school system in order to acquire cultural capital. The Greek system has its own aesthetics, which identifies its members through T-shirts, sweatshirts, sports hoodies, key holders, briefcases, etc. American society is known for its values of "manifest equality and subtle inequality". In matters of campus life, to belong to a fraternity is a diacritical sign, which can be seen as a distinction mark (Bourdieu, 1979).

Fraternities also support alumni organizations, that is, groups of former students who remain closely attached to their alma mater. The latter term, inherited from the British tradition, refers not only to the environment of 
ideas, values, norms, attitudes, but also to natural and architectural aspects characterizing and giving life to an educational institution-that is, its philosophy, history and geography. Many colleges are well known for promoting artistic activities or encouraging interest in sports among its students, while others value community activities, for instance.

Relations between colleges, universities and their fraternities may vary significantly. Fraternities carry out philanthropic actions, such as granting scholarships. Colleges benefit from these, as well as from the financial support by alumni belonging to fraternities located on their campi. On the other hand, fraternities may appear as a parallel source of power. Students sometimes feel closer to fraternities than to colleges, and may disregard the latter's norms. In many American states, for instance, the minimal age for drinking alcohol in public spaces is 21 years. In these cases, most undergrads are not allowed to drink socially. In order to avoid fines, merchants request I.D.'s from those who order alcohol. Especially among young males, fraternities thus become safe havens for underage drinking, and that sometimes means behaving in an anti-social manner.

For some professors with whom the author had the opportunity to discuss this issue, fraternities were seen as anachronistic and elitist, and some were regarded as marked by anti-intellectualism and overdrinking. Most of these professors however had not belonged to a fraternity or sorority when they were at university.

During a three-month period in Dartmouth College in 2003, the author took the opportunity to do some research on the fraternities. In the interviews carried out with brothers and sisters, they showed significant attachment and pride for belonging to their respective fraternities or sororities. The Greek system, as much else in the United States, is highly segmented in social terms. One of the brothers interviewed referred to the "white letters"-fraternities mostly made up of whites, including from the WASP (white, anglo-saxon and Protestant) elite.

As higher education gradually opened its doors to minorities, which used to be mostly excluded from the university, some fraternities emerged which embraced hyphenated Americans: Native-Americans, African-Americans, Asian-Americans, Hispanics. Those considered to be whites are non-hyphenated, supposedly of EuroAmerican origins, and many of them belong to the ruling elites.

In a conversation with a sister, the author asked about her reasons for choosing that particular sorority. She said that she had come from another state, that her parents had not gone to college, and that she was not well aware of the differences as soon as she arrived in Dartmouth. She therefore sought to inform herself before choosing. I asked her the characteristics of the sororities for which she had not applied. She replied that some were too festive, while others were all about studying and being academically brilliant; yet others gathered athletes that were dedicated to sports competitions, and another was made up of girls interested in cooking, who sought to find a husband in college. She had chosen her sorority for being more recent, with a less established profile, assembling young women like herself. She underscored that belonging to a sorority was of great support during her adaptation to the new life on campus.

During the author's visits to fraternities and sororities, the presence of certain objects was especially remarkable: flags, multiple frames in the walls with pictures of all students who had been accepted in the fraternity each year. The rooms were small with a bed (sometimes bunker bed), a wardrobe and a desk. There were also libraries and study rooms - all of them small, since the college library, located one block away, offered books, computers, as well as ample and comfortable spaces to read and study. There was also a large leisure room with a tennis table and a TV set. Social spaces were ample, with comfortable couches and dinner tables that could be displaced in order to make room for the parties. The houses visited had thrown parties recently, and the furniture was all piled up in the salon. In the fraternity, there were boxes filled with empty alcohol bottles and cans. Fraternities are privileged sociability spaces. There are alliances and rivalries between them, and they hold multiple social activities.

But what is the difference between the Greeks and other kinds of student housing?

Many colleges and universities provide housing for students-especially undergrads. Dorms run by colleges are usually located close to the central core, along with the classrooms, library, Dean's office, bars, restaurants, and so forth. Students are assigned to their rooms by a manager, who tries to comply as much as possible with the characteristics and preferences registered in their applications. Practical issues guide this decision, such as whether the student is or not a smoker, or is an early or late sleeper, so they may be placed among other students with similar tastes and routines. The student may change rooms or residencies, as long as vacancies are available.

Besides the dorms, which are open to all (male and female) students, there may be special housing dedicated 
to specific groups. In Dartmouth, for instance, there was a Latin American House. The author asked the person in charge of the Latino students' application, adaptation and supervision, whether that was an independent house where the students made their own rules. He replied that residents had many freedoms but since it was part of college housing, admission criteria were given by the institution. Asked whether being a Latin American was a pre-requisite for applying, the interviewee also answered in the negative: any student enrolled in the college who show interest in the study of Latin America in his or her C.V. is eligible to apply. Those who are admitted also have to comply with some norms. For instance, the house manager requests that once per week students must gather for a common meal sponsored by the college, where the purpose is to bring the group closer together. Once a month, the house organizes an artistic or cultural event (movie screening, photo exhibit, lectures, etc.) related to Latin America and open to the general public.

\subsection{On Continuity and Change: The Development of Higher Education}

From the first colonial colleges to the "multiversity" of our days, American higher education expanded significantly to become one of the world's largest and most complex systems. In a synthesis of its development, some of its characteristics will be presented, emphasizing those moments when challenges posed by society and the federal government led to changes in the system.

\subsection{The Land-Grant Colleges and Extension Activities}

Before the first half of the nineteenth century, higher education in the U.S. had an almost exclusively classic orientation. Although institutions had gone through a process of secularization whereby certain majors such as Medicine or Law became part of the students' general training, their curricula were criticized for lacking technical education directed to the country's economic development. Farmer groups demanded a more democratic education, applied to their own realities. Since the states did not have enough resources for supporting this kind of education, Senator Justin Morril presented in Congress a new Bill of Law channeling federal funds to colleges offering training in the field of agriculture. Upon approval, this Law gave origin to the land-grant colleges. The federal government donated land for the states to use as they thought appropriate, in order to create state universities directed to the practical needs of each region (Lucas, 1994).

Many obstacles were faced early on: the majors' low prestige, students lacking academic foundations, illprepared professors, scarcity of appropriate didactic materials. Agronomic experimental stations supported the progress of knowledge that was taught in these colleges. Medium-sized farmers also criticized the theoretical character of teaching, and pressed for a kind of knowledge that would meet their daily needs. This demand led some colleges to offer short courses for farmers, which eventually gave rise to extension activities-a typical American contribution to the general notion of what a university should do.

\subsection{Scientific Development and Research Universities}

Towards the end of the nineteenth century, a different higher education model was introduced in the United States: the German research university, based on Humboldt's ideas. Research became part of life in the universities, which took on a more comprehensive role. They came to include colleges (courses taught during the first years of undergraduate education), professional schools, and extension, as well as research and graduate programs. Some even maintain the divinity colleges to this day.

The changes brought about by the development of research activities in universities only became possible after a long and disputed secularization process in the American higher education system. It is interesting to note that this became easier as colleges consolidated as a four-year period of general training, before continuing to the professional majors of Medicine, Law, lato sensu graduate programs of M.A.'s and Ph.D.'s. Colleges were therefore in charge of offering basic training to undergraduates, preparing them for a scientific or secular professional formation.

At the turn of the twentieth century, philanthropic support was very important in the creation and development of labs based on the universities. Many donors imposed conditions within campus. Also common were donations for building football stadiums. The two world wars changed this scenario, by pushing the federal government decisively in the direction of valuing and systematically supporting basic research. In the beginning, funds were channeled to the physical sciences; later on, the biological and social sciences were also contemplated, and 
eventually, the incentive also reached the humanities (Geiger, 1986). At research universities, departments became stronger and more central to the development and consolidation of academic disciplines. Different from the German chair-holder who concentrated all the power, in the United States the departmental heads managed the funds according to long term planning, in some cases even interfering in the selection and hiring of new professors. In order to boost research, graduate programs were established for training new researchers.

Not all American universities became research universities. There are many state universities directed to training teachers and other professionals. Some of the older colleges remained attached to their original mission, and have not diversified their functions significantly. Many small private universities did not achieve the quality level necessary for becoming research and graduate institutions.

\subsection{Democratizing Education and the Community Colleges}

In the early twentieth century, junior colleges emerged in small towns. They offered the first two years of college, and were aimed at transferring students in good standing who wished to conclude their studies at a university college. Later on, junior colleges began to offer technical majors, thus becoming community colleges. These colleges welcome a large number of students-in California and New York, for instance, enrollment is open to all those showing the ability to keep up with higher education, even without a high school diploma. Besides transferring academically oriented students, these colleges also offer full majors (some of four years) aimed at the practical needs of local job markets. Most community colleges are part of the states' public system (Diener, 1986).

Besides the community colleges, a federal scholarship program for Second World War veterans further contributed to the expansion and democratization of American higher education. These scholarships favored the system's diversification, since the grantees were free to choose the kind of education that they wished. Once this latent demand was met, system expansion was expected to stall. The influx of women, minorities, and elders entering college for the first time, or for continuing their studies, kept enrollment in higher education constant.

\section{Higher Education in Brazil}

\subsection{The Founding Institution: Brazilian Faculdades}

During the colonial period, there were no higher education institutions within Brazil's territory until the early nineteenth century. Students belonging to the Portuguese colonial elites-considered to be Portuguese born in Brazil-had to move to the metropolis in order to graduate. In the colony, formal education was offered by the Society of Jesus. The Jesuits were dedicated to Christianizing indigenous people organized in settlements, to training the clergy in theology seminars, and to educating the sons of the ruling class in royal schools. The latter offered Medieval-Latin education with Greek elements, preparing the students to attend the University of Coimbra in Portugal. This university's mission was to unify the Portuguese Empire elite culturally. In the spirit of Counter-Reformation, it sought to imprint cultural homogeneity into the children of Portuguese elites born in the colonies, preventing them from questioning the Catholic faith as well as the metropolis's superiority over the colony. In the words of Anísio Teixeira, the University of Coimbra was Brazil's "first university". During the colonial period, over 2500 students born in Brazil received degrees from that institution, in the fields of Theology, Canon Law, Civil Law, Medicine and Philosophy (Teixeira, 1989).

In 1808, the Portuguese Royal Family left Lisbon for Brazil, fleeing Napoleon's troops as they marched into Portugal. When the ruling prince Dom João VI arrived in Bahia, local merchants demanded the establishment of a university, and committed generous financial contributions to its budget. Instead of a university, a Course of Surgery, Anatomy and Obstetrics was created in Salvador. When the Court moved to Rio de Janeiro, the city became home to a newly created School of Surgery, Military Academy, and School of Fine Arts. A National Museum, National Library, and Botanic Garden were also established.

It is important to remark that the first Brazilian Schools, established in the nineteenth century-of Medicine, Law, Polytechnic - were secular, professionally oriented, and independent from one another. Their didactic organization and power structure were based on life-long chairs. Brazil’s independence in 1822 did not significantly alter the scenario of higher education. During the Empire, two Schools of Law-one in Olinda, another in São Paulo-were established, and the mining region of Ouro Preto became home to a School of Mines. These Schools were called Faculdades. 


\subsection{On Continuity and Change: The Development of Higher Education}

Both Faculdades and Universities emerged late in Brazil. The University of Rio de Janeiro was the first of its kind, and it is still active. It was created by decree in 1920, as an aggregation of previously existing Faculdades. Neither its purpose nor its mode of operation offered new alternatives in higher education. It maintained the professional orientation of all courses, the compartmentalization of the Faculdades, a chair-based power structure, and the elitist character of education. It therefore remained far removed from the needs of most Brazilians, and did not encourage scientific and technological development (Fávero, 1980).

Francisco Campos, Brazil’s first Minister of Education, enacted in 1931 the Statute of Brazilian Universities, which remained in force until 1961. According to it, the establishment of a new university required the inclusion of at least three of these Faculdades: Law, Medicine, Engineering, Education, Sciences, or Letters. These Schools were linked by administrative ties, but could maintain their legal autonomy.

The creation of the University of São Paulo (USP) in 1934 introduced a break in this traditional model. It may be considered the first successful attempt at creating a Brazilian university capable of innovating in terms of its objectives. Scientifically, USP became notorious as a research center in several fields of knowledge. It is by far our best known university. Organizationally, however, the idea of making the Faculdade of Philosophy, Sciences and Letters a central integrative core for all basic teaching failed. This was partly due to the resistance of traditional Professional Schools, which did not wish to relinquish the selection and training of students since their first year.

The city of Rio de Janeiro then Brazil's capital, became a privileged stage for the organization of various social groups, which struggled for hegemony over defining the role of Brazilian universities. Three new universities were created there-the University of the Federal District, the University of Brazil, and the Catholic University-which somehow reproduced the ideological cleavages prevalent among educators at the time.

In 1935, Anísio Teixeira, the Federal District's Teaching Director, established the University of the Federal District by municipal decree. The university was directed to the renovation and expansion of culture, and was a great victory for the liberal educators. Due to his political stance in favor of free public schools, Anísio Teixeira's initiative did not receive support from the federal government, neither from sectors linked to the Catholic Church.

Afflicted by an unfavorable political atmosphere and direct interference from the central government, the University of the Federal District lasted for only four years. Discontinued by presidential decree in 1939, its courses were transferred to the University of Brazil-the new name for the pioneer University of Rio de Janeiro. The brainchild of Capanema, then the Education Minister, the University of Brazil would become a model for all higher education institutions in the national territory, thus consolidating a higher education standard for the country at large (Schwartzman, 1994).

On the other hand, Brazilian catholic intellectuals at the time feared liberal ideas as well as American influence on education. They regarded both as a threat to Catholicism in the country. The first catholic university in Brazil brought together the already existing Faculdades of Law, Philosophy and Social Services, under the administration and pedagogic orientation of the Jesuits. The Holy See granted it the title of "Pontifical", and the university became an example for other catholic universities to be established in the national territory.

Between 1945 and 1964, Brazilian higher education underwent a phase of integration, with the creation of new universities based on previously existing Faculdades and the federalization of many state universities. Towards the end of the populist period, 65\% of higher education students were enrolled in universities. This became a long-lasting university model, organized around the traditional Faculdades that offered professional courses for the ruling elites (Cunha, 1983).

In 1961, the first National Education Bases and Guidelines Law was enacted. Even though it provided for some flexibility, in practice it ended up consolidating the traditional model: it maintained the lifetime chair system, isolated Faculdades, and universities made up of the latter's juxtaposition, with no special concern for research.

That same year, the University of Brasilia (Unb) was established. It was the first university in Brazil born out of a well-defined plan, with no inclusion of preexisting professional Faculdades. Part of the national-development project, the university's integrated, flexible and modern structure stood against the model of university fragmented into compartmentalized Faculdades. At Unb, the department replaced the chair as unit of research and teaching. The innovations introduced along with Unb became, in part, a model for the university reform that 
would happen in the late sixties.

\subsection{The 1968 University Reform and the Graduate System}

Upon seizing power in 1964, the military came to wield direct influence on the universities. A large number of professors, especially from the University of Brasília, were removed. Government established information units within the federal higher education institutions, in order to control "subversive" activities by both professors and students. In 1968, a year of multiple student demonstrations in many countries, Brazilian students also mobilized. Excedentes - that is, students who had passed in the entrance exams in highly selective university courses such as medicine and were not assigned a seat-organized to demand more vacancies. In some universities, parallel courses were created by the excedentes themselves.

University reform debate, which at the beginning of the military regime had remained a latent issue gained political muscle. It was discussed between the walls of state bureaucracies in a very technical approach. The National Congress approved within a few weeks the Law number 5440/68. This reform commanded the substitution of chairs for departments, whose head rotated among faculty. The character of vestibular entrance exams changed from eliminatory to classificatory. Since then, each student may choose more than one course upon enrollment in the vestibular; this helped redirect applicants from most to less coveted courses. New, short-term courses were created, especially in teacher training and technical fields. A credit system was encouraged, and a "basic cycle" was established for all freshmen. These measures sought a better deployment of existing seats, by rationalizing available resources and enhancing the number of students enrolled in public universities without increasing the overall budget.

In parallel to this, the reform established the joint character of teaching, research and extension, as well as full-time, exclusively committed professors, valued for their degrees and scientific production. The reform was a watershed in the professionalization of university professors, the development of a graduate system and of scientific production in Brazil. The Law number 5540 was directed especially to federal higher education institutions. According to the legal text, the university was the institutional model to be followed; isolated institutions should be an exception for specific cases. The university was in charge of developing teaching, research, and extension: these three basic functions came to be considered undissociate.

The federal system remained faithful to the reform's orientation, and gradually broadened access to its undergraduate courses by rationalizing resources and without opening up isolated Faculdades. The largest public universities took advantage of the funds for research and training being provided by the government in order to establish a graduate system. This system has provided for the qualification of professors and development of research in Brazil.

Several factors advanced the implantation and development of graduate studies in Brazil. Firstly, following the conservative modernization project championed by the military, high-level human resources became increasingly valued, especially in technical fields. This aim was achieved through the deployment of funds specific for the development of strictu sensu graduate programs. Agencies supporting scientific development were central to this. The Coordination for the Improvement of Higher Education Personnel (CAPES) sponsored the qualification of a significant number of professors abroad, and later on in well-established national graduate programs. The National Council for Scientific and Technological Development (CNPq) funded research projects and distributed scholarships for research professors and graduate students.

Public universities thus became the chief locus for research activities, which at that moment were still incipient in Brazil. Professor career in federal universities began to encourage young professionals with M.A. and Ph.D. degrees and scientific production, to follow a university career. Their professionalization was secured by full time, exclusive commitment-by then, something new in the country. These measures introduced important incentives for public university professors, attracting young people to academic life. They engendered the conditions for developing graduate programs and research activities, which became highly valued aspects of Brazil's university system. The country counts today with a graduate system that is considered to be a reference among developing countries.

\subsection{Segmentation of the Higher Education System}

After the university reform, the number of higher education enrollments increased exponentially. This altered the system's general profile, especially by sharpening internal segmentation. System expansion bifurcated into two 
axes, qualitative and quantitative. The highest number of undergraduate enrollments happened in the private sector, in isolated Faculdades of low academic quality - thus giving rise to a parochialization of higher education (Oliven, 1990). This quantitative expansion did not change the professional orientation of the courses, which has been a mark of Brazil's higher education since its origins in the early nineteenth century.

The public sector, on its turn, took on the leadership in the development of research and graduate studies. This qualitative expansion modernized an important segment of the Brazilian university system. The system's dualism was manifested not only in terms of the public vs. private polarity, where the former concentrated most universities, while the latter harbored the largest number of small isolated Faculdades. An internal segmentation emerged within the public sector itself, as graduate programs expanded and became stronger, while undergraduate courses were increasingly neglected. Information technologies became the chief mediator in increasingly de-personalized application processes, where prospective students are selected based mostly on their score in multiple-choice exams.

Authoritarian governments were sympathetic to the expansion of undergraduate studies in the private sector. Fragmentation of the expansion enrolments into individual small and isolated Faculdades discouraged political mobilization by students. Public universities, on their turn, were regarded as subversive centers; in order to become trustable to the eyes of the military, they underwent "ideological cleansing" processes which cost the jobs of many professors.

With re-democratization of Brazilian society, the parochial character of many small Faculdades became anachronistic and economically unfeasible. Thus, in the eighties, many private universities were created based on the integration of individual Faculdades. Later on, large universities in the private sector were responsible for the highest growth in enrollments.

\section{Drawing Parallels}

As was pointed out, the college tradition in the United States began with Harvard in the early seventeenth century. Colleges were born private, closer to their Board of Trustees than to the British Crown, and had a deeply religious character. Since one of their objectives was to train pastors, character formation was very valued. With secularization, colleges eventually turned to students' general formation and citizenship development, also offering practical disciplines oriented to local job markets through the community colleges.

The transition from colleges to universities was a long and complex process, with multiple outcomes. Not all institutions followed this linear path: some have kept their original educational mission — that is, to dedicate less to research than to high quality teaching. Other colleges catered to growing demands for higher education, with no resources or aspiration to become universities. Colleges' origins are, in sum, non-professional.

The first higher education institutions in Brazil were created in the early nineteenth century by a central government actor, Dom João VI. These Faculdades-Schools of Medicine and, later on, Law-were located in Brazil's main cities and were highly elitist. They followed the Napolionic model of the Great French Schools, which were secular institutions aimed at training professionals, oriented less to research than to teaching. Their didactic organization and power structure were based on the lifelong chair system. The chair professor was identified as the "Permanent Lecturer" who supposedly dominated a field of knowledge. He would choose his assistants and remain at the top of academic hierarchy for life.

In Brazil, chair professors from traditional courses such as Medicine and Law used to be renowned professionals only partly dedicated to teaching. They were professional examples to be followed. In the United States, professors were moral examples; they lived in the colleges among the students, and took on a symbolic responsibility for the latter's character-the in loco parentis function.

In Brazil, Faculdades have been located in large cities from the start. University campi removed from urban centers are a later development, itself an influence of the American model. "Freshmen parades", which used to be quite popular, were carried out for the city residents. Lectures, artistic performances, exhibits were open to those living close to the historical buildings of old Faculdades. Distant campi usually do not attract people from outside the academic community.

In general, the architectural plan of traditional American colleges and universities is structured around a central green, where all main buildings are located. Turned upon themselves, they were a social microcosm bearing little relationship with the city where they were located. Between the seventeenth and nineteenth centuries, colleges and universities identified largely with the rural values of American society. 
In the United States, public higher education is an attribution of state governments. There is nothing like Brazil's federal university system. A project for creating a national public university serving as a standard for the entire territory was discussed a number of times, but the idea never really took off. In Brazil, something of the kind was achieved for a moment with the University of Brazil, which was poised to stand as a model for all others. In both countries, colleges and Faculdades preexisted the universities. In the U.S., large universities integrated colleges and professional schools, extension agencies, research and graduate programs, thus forming a multiversity. Students enter the university through college; only after commencement do they move on to a professionalizing course and become graduate students in Medicine, Law, or M.A.'s and Ph.D.'s for instance in Chemistry, History or Literature.

Today, the college academic experience is characterized by being broad and flexible. In the case of university colleges and those following an academic orientation, after the first four years the student must have concluded a major, and sometimes a minor (that is, a range of courses related to a discipline such as Anthropology or Biology, or to a topic, such as Latin America or Public Policy). Majors and minors may or not relate to each other. Since there is no standard entrance exam between courses and universities, majors and minors do not have to be directly related to the professional trajectory that the prospective student wishes to follow. During college, most students choose disciplines that will become a foundation for their further professional training. In some situations, however, good candidates that stray from the conventional standard in highly selective courses may be valued. This is the case of an acquaintance of the author, a Harvard graduate American doctor, whose major was in dead languages (including Aramaic), and a prospective student to the School of Medicine who studied arts in college-as she explained, that was her last chance of having a broad formation before entering graduate school. Colleges' orientation is therefore non-professional.

In Brazil, Faculdades were professionally oriented from the beginning. The prospective student has to choose a professional direction even before entering the university, during his or her preparations for the vestibular exams-one's profession is therefore registered in the undergraduate diploma. At commencement the student cola grau - that is, takes an oath binding him or her to a good performance of that profession.

Further entrenching the professional orientation of undergraduate studies in Brazil are governmental policies that safeguard the graduates rights and privileges through the regulation of professions. Occupations that in the United States are not regulated by law are so in Brazil. And those that do not have their practice regulated, struggle for legal recognition.

Colleges were never professionalized like Brazilian Faculdades. On the contrary: from the twentieth century onwards, they became a pre-requisite for those seeking to pursue professional studies-a requirement that did not exist previously. Colleges have also been democratized by social demands coming from increasingly heterogeneous groups, such as lower classes, minorities, senior citizens, and so forth. This democratizing function was later on taken up by state governments, which have been responsible for enrolling high numbers of students in the new, increasingly urban colleges and universities. In Brazil, higher education has also expanded. But it was up to the private sector to increase the supply of undergraduate seats-first, in isolated Faculdades in the hinterlands and urban peripheries, and later on through universities that enroll millions of students, mostly located in large metropolitan areas.

\section{Conclusion}

The purpose of this study has been to call attention to the symbolic meaning of founding institutions in the development of higher education systems in two countries. American society during the first half of the seventeenth century was quite different from that of the early twenty first century, but the idea of the college as an institution that shapes characters, offers general formation, provides personal development and citizenship remains in force in all kinds of colleges-from the old and most traditional to land-grant colleges, university colleges, junior colleges, community colleges, and colleges located in large metropolitan areas.

In Brazil, the first Faculdades trained a professional elite: the bacharéis (Adorno, 1988), who helped establish a legal order for the new nation. Then they turned to medical doctors and engineers, in charge of devising and implementing sanitary policies and the engineering works that were vital for the new Brazilian Republic (Nadai, 1987). They also became the great educators of their time. There goes a long way between the first Law schools dating from the nineteenth century, and the establishment of Law Faculdades in today's hinterlands. Nonetheless, both have something in common: students take an oath upon graduation, and are accredited for practicing a 
profession—even if, in this case, these credentials have to be further validated by an exam conducted by Brazil's Order of Lawyers.

These differences help make sense why, upon its inception in 1934, the University of São Paulo, was able to put in practice its ideal of research and stand above others as a knowledge-production institution, while the attempt to make the Philosophy Faculdade the new university's integrative core failed. The traditional Faculdades strongly opposed the new Faculdade of Philosophy's attempt to take charge of the selection and general formation of the university's students before they entered professional schools. This would have amounted to performing a college function, thus undermining the power of professional Faculdades. Moreover, the São Paulo elites were at first reluctant to send their children to a new institution, with little tradition in the country.

Another significant moment was the 1968 University Reform. Its influence is felt to this day, in many other aspects such as the credit system, the departments, the development of graduate studies, the classificatory character of vestibular exams, etc. Little is left however, the "basic cycle" experience-a failed attempt at implementing in Brazil something similar to the American college. Let us not forget that Brazil never really abandoned the professionalizing character of the undergraduate courses offered by Faculdades and universities, which still provide the graduates with a professional identity.

United States and Brazil have quite different higher education models. But both still sustain, to a large extent, their respective marks of origin. This study sought to show how this mark made itself present throughout the development and expansion of both systems.

\section{References}

Adorno, S. (1988). Os Aprendizes do poder: o bacharelismo liberal na política brasileira. Rio de Janeiro: Paz e Terra.

Bourdieu, P. (1979). La Distinction. Paris: Editions de Minuit.

Brubacher, J., \& Rudy, W. (1976). Higher Education in Transition (3rd ed.). New York: Harper \& Row Publishers.

Cunha, L. A. (1983). A Universidade crítica. Rio de Janeiro: Francisco Alves.

Diener, T. (1986). Growth of an American Invention: A Documentary of Junior and Community Colleges. Westpoint: Greenwood Press.

Fávero, M. de L. (1980). Universidade \& poder. Rio de Janeiro: Achimé.

Geiger, R. L. (1986). To Advance Knowledge: The Growth of American Research Universities 1900-1940. Oxford: Oxford University Press.

Graham, R. B. (1990). The Dartmouth Story: A Narrative History of the Colleges Buildings, People and Legends. Hanover: Dartmouth Bookstore Inc.

Leslie, W. B. (1992). Gentlemen and Scholars: College and Community in the "Age of the University,” 1865-1917. University Park: Pennsylvania State University Press.

Lucas, C. J. (1994). American Higher Education: A History. New York: St. Martin’s Griffin.

Nadai, E. (1987). Ideologia do progresso e o ensino superior. São Paulo: Loyola.

Oliven, A. C. A. (1990). Paroquialização do ensino superior: Classe média e sistema educacional no Brasil. Petrópolis: Vozes.

Rudolph, F. (1990). The American College and University: A History. Athens, GA: University of Georgia Press.

Schwartzman, S. (1994). Tempos de Capanema. Rio de Janeiro: Paz e Terra.

Teixeira, A. O. (1989). Ensino superior no Brasil: Análise e interpretação de sua evolução até 1960. Rio de Janeiro: Fundação Getúlio Vargas. 
Scientific Research Publishing (SCIRP) is one of the largest Open Access journal publishers. It is currently publishing more than 200 open access, online, peer-reviewed journals covering a wide range of academic disciplines. SCIRP serves the worldwide academic communities and contributes to the progress and application of science with its publication.

Other selected journals from SCIRP are listed as below. Submit your manuscript to us via either submit@scirp.org or Online Submission Portal.
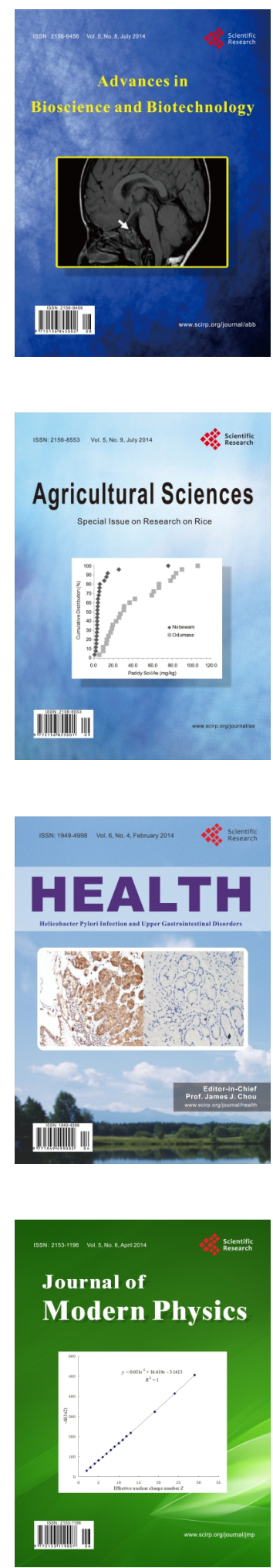
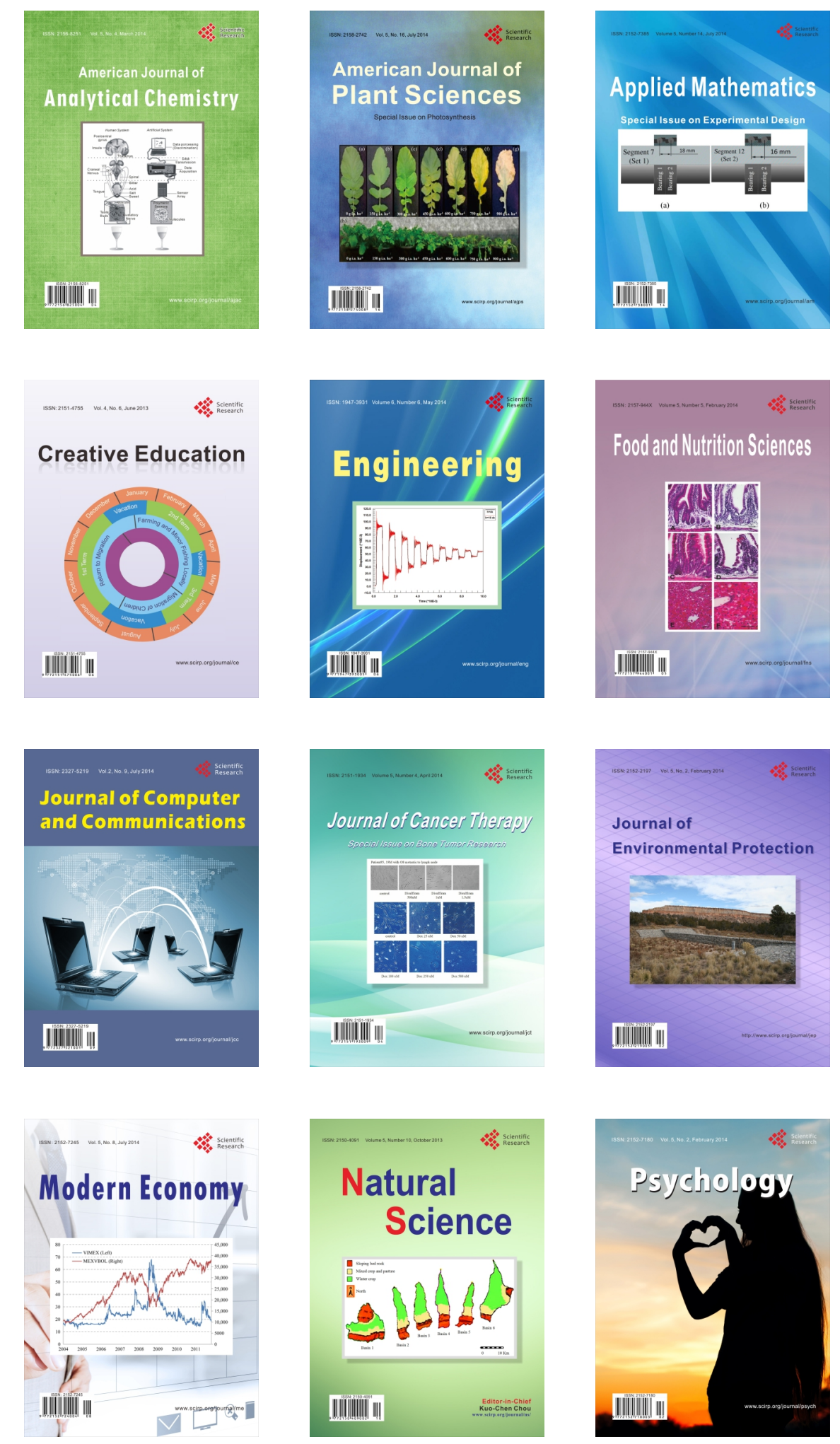